\title{
VICROSKI, F. J. N. Breve contextualização arqueológica e etnohistórica de Porto Alegre e região. 1. ed. Porto Alegre: Sírius Estudos e Projetos Científicos, 2020. 75 p.
}

\author{
Bruno Stori ${ }^{1}$ \\ Helena Putti Sebaje da Cruz ${ }^{2}$ \\ Kauana Silva de Rezende ${ }^{3}$ \\ Walter Ferreira Gibson Filho ${ }^{4}$
}

Fabrício José Nazzari Vicroski é arqueólogo com doutorado em História pela Universidade de Passo Fundo e atualmente desenvolve seu pós-doutorado como pesquisador bolsista PNPD Capes. O atual livro tem como principal objetivo a divulgação científica da pesquisa arqueológica centrada em Porto Alegre e região metropolitana, e a delimitação temporal são os períodos pré-colonial e colonial com enfoque nos povos indígenas e afrodescendentes. O livro, assim como a pesquisa levantada para sua produção, são advindos da empresa Sírius Estudos e Projetos Científicos

\footnotetext{
${ }^{1}$ Estudante do $5^{\circ}$ período do curso de História (Licenciatura e Bacharelado) na Universidade Federal do Paraná. É bolsista do PET História UFPR.

${ }^{2}$ Estudante do $3^{\circ}$ período do curso de História (Licenciatura e Bacharelado) na Universidade Federal do Paraná. É bolsista do PET História UFPR.

${ }^{3}$ Estudante do $7^{\circ}$ período do curso de História (Licenciatura e Bacharelado) na Universidade Federal do Paraná. É bolsista do PET História UFPR.

${ }^{4}$ Estudante do $7^{\circ}$ período do curso de História (Licenciatura e Bacharelado) na Universidade Federal do Paraná. É bolsista do PET História UFPR.
} 
LTDA, com suporte do Núcleo de Pré-História e Arqueologia vinculado ao PPGH da Universidade de Passo Fundo.

A obra é dividida em duas partes, sendo a primeira sobre "O conhecimento arqueológico". No início desse primeiro capítulo, o autor trata sobre a diversidade de fauna e flora na região, que propicia uma alta quantidade de sítios arqueológicos devido a grande movimentação sazonal desses grupos pesquisados. Pelo alto número de sítios arqueológicos na região (Vicroski dimensiona um número próximo a cem), o autor já levanta a pauta da importância da preservação dos mesmos pelas políticas públicas, questão levantada diversas vezes ao longo do livro.

Colocada a importância da preservação, o pesquisador demonstra a gama variada de pesquisas desenvolvidas por inúmeros colegas de ofício, delineando as que são de maior notoriedade: Gislene Monticelli, Júnior Domiks, Francisco Silva Noelli e outras instituições que apoiam e produzem pesquisas arqueológicas em Porto Alegre. A defesa do patrimônio arqueológico em conjunto com órgãos de fomento a cultura é um assunto extremamente importante levantado e defendido por diversos estudiosos da área, como Ulpiano Meneses (2007) e Ana Flávia Sousa Silva (2014), e também é uma discussão importantíssima dentro dos estudos históricos e percepção temporal, como escreve François Hartog (2006).

Vicroski indica que essas descobertas apontam para assentamentos humanos de ao menos 9000 anos de idade. Com essa grande periodicidade de tempo também é necessária uma divisão e classificação dos diferentes 
Cadernos de Clio, Curitiba, v. 9, nº 1, 2018

materiais a partir da cultura material, o que é feito em seguida. A distância temporal é utilizada para formular esta parte: o autor cita primeiro as mais distantes (com povos nômades caçadores e coletores) e por último as mais próximas, fazendo com que, no final do capítulo, o autor consiga estabelecer algumas trocas e relações culturais com o período colonial e com as culturas que perduram até os dias atuais, tal qual a cuia de chimarrão, que é uma herança do estilo de cerâmica e do consumo da erva de tribos jê e guarani.

Ademais, demonstra-se a disposição e movimentação geográfica destes povos nômades, posto que, a partir da organização e catalogação da cultura material, podemos identificar as informações necessárias através da cerâmica produzida e comparar com outras áreas e localidades onde peças com a mesma estrutura no formato e arte são encontradas. Desta forma, o autor cita povos indígenas de diversas áreas como a Argentina, Uruguai e até mesmo Amazônia, tornando explícitas as razões da região de Porto Alegre abrigar a vasta variedade arqueológica já citada anteriormente.

A segunda parte, "O conhecimento etnohistórico", introduz questões acerca dos povos indígenas, africanos e afrodescendentes no período colonial, já se utilizando da história oral e escrita histórica preservada por esses povos ou relatos de contato com os mesmos. $\mathrm{O}$ autor deixa claro como os saberes indígenas foram de extrema importância para o início da colonização do local, já que tais populações possuíam vasto conhecimento da região que, por possuir extensa malha hidrográfica, necessitava de guias para a navegação fluvial. 
Cadernos de Clio, Curitiba, v. 9, nº 1, 2018

A relação de conquista e demarcação territorial fez com que os grupos indígenas e europeus entrassem em conflito direto por todo o período colonial. Os indígenas se movimentaram sazonalmente e os colonizadores em contato acreditavam que eles estavam abandonando tais localidades e que não voltariam mais. Este desentendimento, assim como diversos outros problemas, provocou a guerra guaranítica, que levou vários indígenas à situação de cativeiro em missões sob regime de escravidão. Contudo, o pesquisador alerta que até hoje, através de resistências diversas, os indígenas nunca deixaram de frequentar a região de Porto Alegre e seus entornos. Logo, essa permanência pode ser traçada como contínua até os dias atuais, como exemplificado pelo artesanato e agricultura.

Os povos africanos e afrodescendentes também são apresentados, já no final do livro, como essenciais para um entendimento etno histórico mais aprofundado não somente da região porto alegrense, mas também do próprio estado do Rio Grande do Sul, posto que são encontrados quilombos em diversas regiões. $\mathrm{O}$ autor explora como esses grupos resistiram e se apresentam até os dias atuais como produtores essenciais nos inúmeros setores econômicos da cidade, como as atividades domésticas nos meios rural e urbano.

O autor ainda salienta que a luta de tais grupos tem sido frutífera, já que através delas conquistaram suas terras historicamente ocupadas. Vicroski dá enfoque ao Quilombo da Anastácia, pioneiro na luta pelos direitos a posse de propriedade quilombola e auxiliou diversos quilombos vizinhos a se estabelecerem formando uma cadeia de suporte mútuo. 
Cadernos de Clio, Curitiba, v. 9, nº 1, 2018

A conclusão do livro se propõe a arrematar as reflexões e destacar a diversidade da região, além de ressaltar a etno-história, em conjunto com a arqueologia, como campos do conhecimento chaves para revelar essa diversidade, que torna não somente a sociedade mais tolerante por reconhecer seus traços culturais, históricos e genéticos, como mais perceptiva com sua própria história, reconhecendo esses grupos indígenas e afrodescendentes.

Vicroski obtém sucesso com o objetivo deste livro, demonstrando conhecimento da produção acadêmica sobre o assunto e explicando suas ideias com linguagem didática, lançando mão de imagens e raciocínios leves, para que quem não tem contato com o trabalho desenvolvido tenha um vislumbre básico, mas repleto de conteúdo substancial. O pesquisador se debruça sobre uma importante tarefa, cada vez mais necessária nos dias atuais: a divulgação das ciências humanas e a reafirmação da importância desses saberes. Em momentos não tão otimistas como os quais se vive atualmente, em que bolsas de estudo são cortadas (PORTARIA..., 2020) sem motivo justificável ou em que autoridades se manifestam contra a preservação de sítios arqueológicos em tom jocoso (SPERB, 2019), divulgar a importância da pesquisa na construção de um país mais igualitário é essencial.

\section{Bibliografia}

HARTOG, François. Tempo e Patrimônio. Varia Historia, Belo Horizonte, v. 22, n. 36, p. 261-273, 2006. 
SILVA, Ana Flávia Sousa. Complexo Arqueológico Serra do Morcego, Caxingó (PI): proteção, conservação e manejo de sítios arqueológicos de registros rupestres. 2014. 150 f. Dissertação (Mestrado em Antropologia e Arqueologia) - Universidade Federal do Piauí, Teresina, 2014.

MENESES, Ulpiano Toledo Bezerra de. Premissas para a formulação de políticas públicas em Arqueologia. Revista do Patrimônio Histórico e Artístico Nacional, n. 33, p. 37-57, 2007.

PORTARIA da Capes corta bolsas de diversos programas de pós-graduação. Andes, 24 mar. 2020. Disponível em: $<$ https://www.andes.org.br/conteudos/noticia/portaria-da-capes-corta-bolsas -de-diversos-programas-de-pos-graduacao1>. Acesso em: 08 jul. 2020.

SPERB, Paula. Cocozinho petrificado de índio barra licenciamento de obras, diz Bolsonaro. Folha de S. Paulo, 12 ago. 2019. Disponível em: $<$ https://www1.folha.uol.com.br/mercado/2019/08/cocozinho-petrificado-d e-indio-barra-licenciamento-de-obras-diz-bolsonaro.shtml $>$. Acesso em: 08 jul. 2020.

Recebido em: 10/07/2020 Aceito em: 01/09/2020 